Magdalena Melnyk

\title{
Obraz hiszpańskiej wojny domowej na plakatach
}

\section{Wstęp. Hiszpańska wojna domowa - krótki rys historyczny}

Hiszpańska wojna domowa wybuchła 18 lipca 1936 r., kiedy generał Francisco Franco ${ }^{1}$ podjął próbę przewrotu wojskowego. Praktyka obalania demokratycznie wybranego rządu przez wojsko była w Hiszpanii na tyle powszechna, że doczekała się własnej nazwy - „pronunciamiento”. Zaskoczeniem natomiast okazał się fakt, że pomimo poniesionej porażki (Franco nie udało się przecież obalić rządu bezpośrednio po ogłoszeniu przewrotu!), dopiero swoiste przesilenie polityczne doprowadziło do długotrwałego konfliktu zbrojnego. Miał on zakończyć się w kwietniu 1939 r., na pięć miesięcy przed wybuchem II wojny światowej.

Po dwóch stronach barykady stanęli nacjonaliści, nazywani także frankistami, oraz republikanie, przez propagandę Franco okrzyknięci „czerwonymi", z racji dość powszechnych sympatii lewicowych. Oba obozy były głęboko niejednolite i podzielone. Wspomnieć należy, że po

\footnotetext{
${ }^{1}$ Francisco Franco był szybko awansującym hiszpańskim wojskowym, który w roku 1926 otrzymał szlify generalskie, w tym czasie jako najmłodszy generał w Europie. Po wyborach wygranych przez Front Ludowy w 1936 r., w obawie przed politycznym spiskiem został odesłany na stanowisko komendanta Wysp Kanaryjskich. Była to ogromna degradacja, ponieważ od roku 1935 pełnił funkcję Szefa Generalnego Armii Hiszpańskiej. W lipcu 1936 r. przystąpił do działań konspiracyjnych, mających na celu obalenie Republiki. Początkowo miał być tylko dowódcą wojsk w Maroku, jednakże typowany na przywódcę gen. José Sanjurjo zginął w wypadku lotniczym w pierwszych dniach przewrotu.
} 
stronie frankistów stanęli karliści, dążący do restauracji monarchii, i falangiści - ruch paramilitarny, najbardziej aktywny podczas trwania wojny. Jednakże wart podkreślenia jest fakt, że wszelkie partie i organizacje polityczne działające po stronie nacjonalistycznej były tylko marionetkami w rękach Generalísimo Franco.

Aby zrozumieć skomplikowaną sytuację polityczną po stronie republikańskiej, należy bliżej przyjrzeć się partiom, które wiodły prym w Barcelonie - centrum oporu przeciwko zbuntowanym siłom wojskowym. W Katalonii od początku wieku XX najpotężniejszą organizacją zrzeszającą masy robotnicze była anarchizująca Narodowa Konfederacja Pracy CNT (La Confederación Nacional del Trabajo), a jej ramieniem politycznym, od 1932 r. kontrolującym wszystkie związki zawodowe podległe organizacji - Iberyjska Federacja Anarchistyczna FAI (Federación Anarquista Ibérica). Partia Komunistyczna nigdy nie osiągnęła większego znaczenia w tym regionie, $\mathrm{w}$ odróżnieniu od Robotniczej Partii Zjednoczenia Marksistowskiego POUM (Partido Obrero de Unificación Marxista). Liczyła ona nieporównywalnie więcej członków, była bardzo dobrze zorganizowana, nie posiadała jednak poparcia Moskwy. Teoretycznie zarzucano jej trockistowskie sympatie, ale w rzeczywistości Sowieci nie mogli jej zaakceptować z uwagi na otwarcie antystalinowski charakter (Miravitlles, Termes 1978: 10). Najpotężniejsza partia lewicowa w kraju - Socjalistyczna Partia Robotnicza Hiszpanii PSOE (Partido Socialista Obrero Español) nie dysponowała dużą grupą członków w tym regionie i dlatego jej znaczenie polityczne podczas wojny było nikłe. Jako przeciwwaga dla CNT w siłę zaczął rosnąć socjalistyczny związek zawodowy, silnie wspierany przez PSOE - Zgromadzenie Powszechne Ludzi Pracy UGT (Unión General de Trabajadores). Chociaż socjalistów w Katalonii było stosunkowo mało, związek rósł w siłę, ponieważ wielu ludzi o poglądach lewicowych wybierało w nim członkostwo, nie chcąc przystępować do anarchistów.

Od początku wojny utrwalił się podział, w którym nacjonaliści opanowali południe, a republikanie północ. $W$ tej sytuacji frankiści kontrolowali Hiszpanię rolnicza, feudalną i biedna, a ich przeciwnicy część przemysłową bogatą i nowoczesną. Trójkąt przemysłowy BarcelonaMadryt-Bilbao pozostawał $\mathrm{w}$ rękach republikanów, natomiast trójkąt feudalny Sewilla-Badajoz-Valladolid w rękach nacjonalistów. Cytując Jaume Miravitllesa (komisarza ds. propagandy w rządzie katalońskim w latach wojny domowej) - "Jest to amerykańska wojna secesyjna, w której Południe wygrało z Północą!" (Miravitlles, Termes 1978: 11). 
Powodem przekształcenia się przesilenia politycznego w długotrwały konflikt zbrojny było wsparcie, jakie zostało udzielone stronom przez państwa obce. Jesienią roku 1936 konflikt pomiędzy „Dwoma Hiszpaniami", rozumiany jako kontynuacja walk politycznych zapoczątkowanych w wieku XIX, których kulminacją było proklamowanie II Republiki w roku 1931, przeistoczył się w wojnę pomiędzy "Dwoma Europami”, a wraz z upływem czasu między „Dwoma Światami”. Był to pierwszy konflikt zbrojny, w którym starły się trzy różne ideologie: demokracja, nazizm oraz komunizm i dodatkowo religia chrześcijańska (zgodnie $\mathrm{z}$ wizją generała Franco, nacjonaliści brali udział w krucjacie $\mathrm{z}$ niewiernymi - „la Cruzada”). W związku z tym powszechnie uważa się, że hiszpańska wojna domowa stanowiła preludium do II wojny światowej.

Pomimo zawartego przez mocarstwa europejskie „Paktu o nieinterwencji", już w pierwszych dniach konfliktu porozumienie to zostało pogwałcone. Jako pierwsze do wojny włączyły się nazistowskie Niemcy, pomagając siłom nacjonalistycznym w przedostaniu się z Maroka na Półwysep Iberyjski, do czego wykorzystano samoloty Junkers F-13. Zarówno Niemcy, jak i Włochy postanowiły wesprzeć frankistów, wysyłając im również własne odziały wojskowe - niemiecki Legion Condor i włoskie Aviazione Legionaria oraz Corpo Truppe Volontarie. To przede wszystkim dzięki dobrze zorganizowanym siłom włoskim udało się nacjonalistom stosunkowo szybko opanować całe południe. Natomiast Legion Condor, jak i inne jednostki działające $\mathrm{w}$ lotnictwie nazistowskim, po raz pierwszy w historii dopuściły się bombardowań celów nieposiadających żadnego znaczenia strategicznego, chodziło przy tym jedynie o zastraszenie ludności cywilnej na obszarze zajętym przez republikanów. $Z$ drugiej strony siły republikańskie mogły liczyć na wsparcie zagranicznych ochotników (w tym tzw. Brygad Międzynarodowych, zorganizowanych przez Komintern), a także stalinowskiego ZSRR i socjalistycznego Meksyku. Pomoc ZSRR była w pełni odpłatna - za dostawy broni i sowieckich doradców wojskowych rząd republikański zapłacił z rezerw Banku Hiszpanii sztabami złota. Gdy hiszpańskie zapasy złota w listopadzie 1938 r. wyczerpały się, skończyły się również dostawy sowieckiego sprzętu wojennego dla Republiki Hiszpańskiej. W konsekwencji cztery miesiące później hiszpańska wojna domowa dobiegła końca, a granica francuska przeżywała oblężenie republikanów masowo udających się na emigrację.

Jak wspomniałam wcześniej, hiszpańska wojna domowa okazała się pierwszym konfliktem zbrojnym w historii wieku XX, podczas którego doszło do starcia głównych ideologii tego okresu - demokracji, faszyzmu 
i komunizmu. Przesłaniem nacjonalistów było "uratowanie Ojczyzny”, odtworzenie "starego porządku” z poszanowaniem religii i tradycji. Natomiast po stronie republikańskiej wybuch wojny domowej doprowadził do radykalizacji haseł anarchistycznych i socjalistycznych, nawołujących do rewolucji i stworzenia nowego ładu społecznego, w którym ważne będą wolność i równość pomiędzy ludźmi. Jak łatwo zauważyć był to konflikt o charakterze społecznym, w którym poparcie mas zdecydować miało o zwycięstwie jednej ze stron. $Z$ tego powodu tak ważna okazała się propaganda, a głównymi środkami przekazu stały się plakat, radio i prasa. $Z$ tych trzech narzędzi masowej komunikacji, po stronie republikańskiej bez wątpienia to plakat święcił największe triumfy, a spowodowane było to faktem, iż okazał się najbardziej efektywny, docierając do największej grupy odbiorców. Wysoki poziom analfabetyzmu spowodował, że to właśnie prosta forma graficzna, z krótkim, chwytliwym hasłem święciła o wiele większe sukcesy propagandowe niż prasa.

\section{Związek Zawodowych Rysowników Katalonii}

Przystępując do analizy plakatów z tego okresu, natychmiast zauważamy, że liczba plakatów tworzonych i rozpropagowywanych po stronie republikańskiej niewspółmiernie przewyższała tę powstałą po stronie nacjonalistów. Składało się na to wiele czynników. Po pierwsze, jak już wspomniałam, siły republikańskie utrzymywały swoje pozycje $\mathrm{w}$ bogatym trójkącie przemysłowym, który już w latach trzydziestych pod względem ekonomicznym znacznie odbiegał od reszty Hiszpanii. Dzięki dobrze prosperującemu przemysłowi i handlowi rósł w siłę sektor reklamowy, a afisze święciły swoje pierwsze triumfy. Po drugie, Barcelona od dłuższego czasu uznawana była za Mekkę artystów, a Związek Zawodowych Rysowników Katalonii został założony już w kwietniu roku 1936, przyciągając najlepszych przedstawicieli tego zawodu. Po trzecie, rysownicy opowiadający się po stronie republikańskiej byli o wiele mniej ograniczani politycznie podczas tworzenia swoich dzieł, w przeciwieństwie do wykonywanych na zlecenie frankistów. Artyści pracujący dla nacjonalistów otrzymywali konkretne wytyczne, z którymi nie mogli polemizować. Ponadto, generał Franco wierzył znacznie bardziej w skuteczność propagandy czynów (rozdawnictwo żywności 
Obraz hiszpańskiej wojny domowej na plakatach

i odzieży, organizowanie stołówek dla dzieci, tworzenie sierocińców itp.), dlatego o wiele mniej środków przeznaczano na twórczość artystyczna, zdaniem Caudillo² znacznie mniej efektywną. Dodać należy, że po stronie republikańskiej działały fabryki papieru i innych materiałów potrzebnych do produkcji plakatów, natomiast nacjonaliści od początku wojny borykali się z niedostatkiem tego typu surowców.

Produkcja plakatów po stronie republikańskiej okazała się bezprecedensowa w historii Hiszpanii zarówno pod względem liczby, jak i jakości artystycznej wydrukowanych projektów litograficznych. $Z$ reguły każdy plakat był powielany w 3-5 tysiącach egzemplarzy, ale według cytowanego już Fontseré (1978: 353-377), niektóre postery powielano nawet w rekordowej liczbie 10 tysięcy sztuk. Produkcja plakatów miała swoje bezpośrednie przełożenie na euforię rewolucyjną i powszechny entuzjazm, jaki towarzyszył stronie republikańskiej. Hasła zamieszczane na plakatach były formułowane $\mathrm{w}$ czasie teraźniejszym i traktowały o podniosłej chwili rewolucyjnej. W pierwszych dniach konfliktu artyści ze Związku Zawodowych Rysowników Katalonii cieszyli się pełną autonomią w kwestii doboru haseł i grafiki, a partie polityczne odbierały gotowe projekty, nie zgłaszając do nich żadnych zastrzeżeń. Ze względu na liczbę wszelkiej maści instytucji i organizacji politycznych działających wspólnie w ramach Frontu Ludowego, która to liczba oscylowała w tym czasie wokół trzydziestu, istniała bardzo duża decentralizacja i różnorodność prezentowanych idei. Z czasem przywódcy polityczni zaczęli narzuć przekaz słowny, jednakże korespondująca z nim grafika była już niezależnym wytworem artysty. Wraz z pogarszającą się sytuacją na frontach i coraz większymi brakami w surowcach, jakość używanego do produkcji posterów papieru i innych surowców stale się pogarszała, a ich liczba malała. Podczas trzech lat trwania wojny po stronie republikańskiej zostało stworzonych około 3,5 tysiąca plakatów litograficznych (Carulla, Carulla 2000: 4) ${ }^{3}$, z których co najmniej połowę można ocenić jako słabą pod względem artystycznym i technicznym. Liczba ta oznacza, że na każdy z tysiąca dni trwania konfliktu przypadają trzy projekty (Carulla, Carulla 2000: 4). Niezadowalający poziom wielu plakatów z tego okresu spowodowany był nie tylko brakiem materiałów, ale także faktem, że projektowały je często osoby przypadkowe. O ile na początku

${ }^{2}$ Z hiszp. „wódz”, nazwa ta odnosiła się do osoby generała Francisco Franco.

${ }^{3}$ Dla porównania inne źródła podają, że powstało ich pomiędzy 1000 a 1500 (Gubern 2008: 47). 
wojny w szeregach Związku Zawodowych Rysowników Katalonii przeważali wybitni plakaciści, tacy jak Josep Renau, Carles Fontseré, Antoni Clavé, Martí Bas, Ramón Gaya, Durbán, Cañavate, Juana Francisca, José Bardasano, Fernando Briones, Yes, Bagaria, Helios Gómez, Rodríguez-Luna, Arturo Ballester, José Goñi, J. Huertas, Vicente Ballester, Enric Cluselles, Manuel Monleón o Xirinius (Julian Gonzalez 2008: 38), o tyle wraz z upływem czasu i coraz większym zapotrzebowaniem na tego typu projekty, sam Związek przyjął do swojego grona około 1800 członków. Dodatkowo, trudna do oszacowania liczba artystów tworzyła skupiona $\mathrm{w}$ innych organizacjach bądź na własną rękę. W żadnym wypadku nie umniejsza to ogromu pracy, jaki wykonali wielcy specjaliści w dziedzinie tworzenia plakatów reklamowych, kinowych, a także nowatorskiego w tym czasie fotomontażu, w którym przodował genialny Joseph Renau.

\section{Retoryka i estetyka plakatu wojennego}

Plakaciści w obliczu rozpoczynającej się wojny, która jawiła się im jako rewolucja społeczna, bardzo chętnie czerpali z osiągnięć amerykańskiego plakatu reklamowego doby Wielkiego Kryzysu, szkoły plakatu niemieckiego, a przede wszystkim z dokonań Rosjan w tym zakresie. Wzorowano się szczególnie na plakatach $\mathrm{z}$ okresu rewolucji bolszewickiej. Nowa „rewolucyjna sztuka katalońska” jako punkt wyjścia traktowała propagandę rosyjską. Działo się tak z kilku ważnych powodów. Po pierwsze, zarówno rewolucja bolszewicka, jak i hiszpańska wojna domowa wybuchły jako konflikty o podłożu ideologicznym. Nowo prezentowane idee musiały dotrzeć do jak największej rzeszy odbiorców i w państwach o wysokim poziomie analfabetyzmu być przez masy $\mathrm{w}$ pełni zrozumiane i przyswojone. Po drugie, $\mathrm{z}$ powodu braku dużych środków finansowych, szukano rozwiązań tanich i dosyć trwałych, dlatego plakat jawił się jako środek o wiele tańszy niż np. droga produkcja kinematograficzna. Ponadto, biorąc pod uwagę fakt, że w omawianym okresie wszystkie środki audiowizualne pozostawały czarno-szaro-białe (fotografia, kino), wielokolorowy plakat zwracał powszechną uwagę. Był „krzykiem dochodzącym ze ścian”. Z tego powodu poster stał się naczelnym narzędziem nazwanego tak przez leni- 
nistów agit-propu, tzn. agitacja i propaganda (Gubern 2008: 47), a jego produkcja bezdyskusyjnie jednym z najważniejszych nurtów artystycznych podczas trwania tych dwóch wojen. Zarówno Rosjanie, jak i Hiszpanie do momentu wybuchu konfliktu nie mieli dużego doświadczenia $\mathrm{z}$ zakresu tworzenia plakatu wojennego. Zgodnie z założeniami wypracowanymi już $\mathrm{w}$ związku z potrzebami I wojny światowej, miał on na celu ugruntowanie głoszonej ideologii pośród własnych członków, zdyskwalifikowanie i zasianie nienawiści względem wroga oraz wzbudzenie pewności, co do wygranej. $W$ tym konkretnym przypadku plakat miał także pełnić funkcję symbolu wyzwolenia spod uciemiężenia kapitalistycznego, wzbudzenia nadziei na lepsze jutro, które zostanie stworzone wspólnymi siłami.

Inspirując się osiągnięciami rosyjskiego poety rewolucyjnego Władimira Majakowskiego w obszarze "liryki sloganów rewolucyjnych", zdano sobie sprawę, że teksty umieszczane na plakatach muszą być krótkie i łatwe do zapamiętania. Ich celem winno być zjednoczenie odbiorców, zwrócenie ich uwagi i zmuszenie do działania. Często uciekano się do pytań kierowanych $\mathrm{w}$ drugiej osobie liczby pojedynczej bezpośrednio do odbiorcy. Sztandarowym przykładem jest tu plakat stworzony przez Andaluzyjczyka Lorezno Goñi Suáreza del Árbol, przedstawiający zbroczonego krwią leżącego żołnierza, który wskazując palcem na widza pyta: „A ty? Co zrobiłeś dla zwycięstwa?”4 (plakat 1 ).

$\mathrm{Z}$ drugiej strony dobry tekst nie wystarczał. Równie ważna była oprawa graficzna, w jakiej go przedstawiono, czcionka, wielkość liter, itd., często o charakterze prawie ikonograficznym (Gubern 2008: 47).

Kolejnym, bardzo ważnym, wyróżnikiem dobrego plakatu było należyte wykorzystanie takich narzędzi, jak umiejętnie dobrane kolory, efektywna kombinacja barw ciepłych i zimnych, nasyconych i nienasyconych, świecących i matowych. Tego typu techniki zostały użyte przez Huertasa, który projektując plakat Bądź czujny! zastosował obok rewolucyjnej,

${ }^{4}$ W oryginale: „I tú? Que has fet per la victòria?” W tym zakresie Hiszpanie nie byli nowatorscy, jak inne nacje dopuszczali się zapożyczeń. Ten typ plakatu został pierwotnie stworzony przez Alfreda Leete na potrzeby ujawnione w trakcie I wojny światowej. Kiedy Stany Zjednoczone przystąpiły do tej samej wojny zamiast Lorda Kitchera to Wuj Sam przekonywał młodych chłopców, że Ojczyzna chce właśnie ich „Wants you”. W Rosji Sowieckiej to ranny żołnierz na chwilę przed zgonem zadawał pytanie, które Goñi wykorzystał wraz z kompozycją do własnego plakatu.

${ }^{5} \mathrm{~W}$ oryginale: ¡Alerta está! 
ciepłej czerwieni zimną zieleń, osiągając tym samym efekt o wiele bardziej przyciągający uwagę (plakat 2). Wszystkie te czynniki nie pozostają bez znaczenia, jeśli weźmiemy pod uwagę, że najpierw dostrzegamy kolor, następnie formę i na samym końcu ruch figur i postaci, a wszystko to w przeciągu tysięcznych sekundy (Gubern 2008: 48).

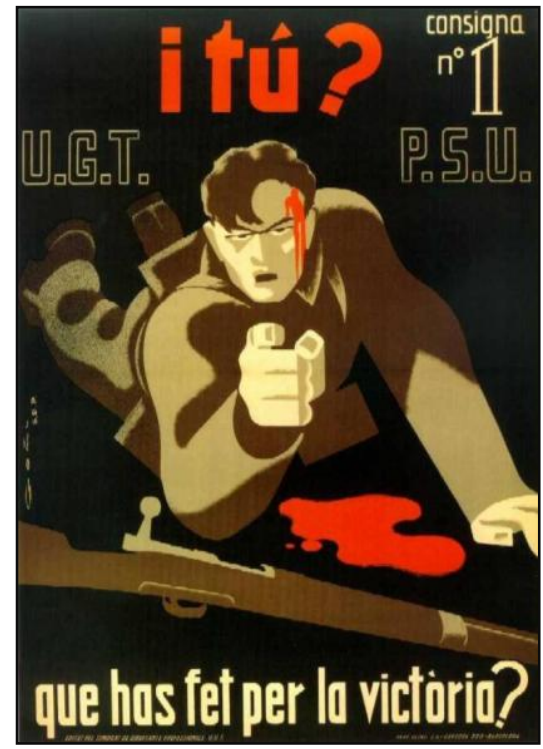

Plakat 1

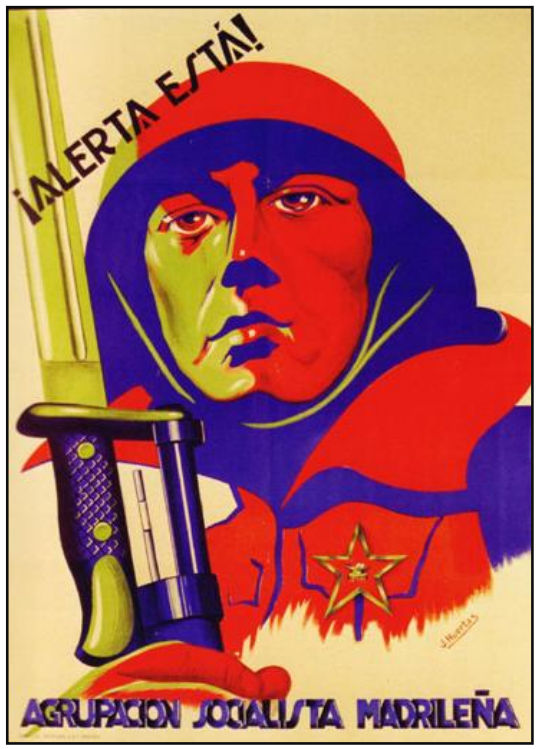

Plakat 2

Obok koloru, niebagatelną wagę miała kompozycja. Aby w sposób przyciągający uwagę wyeksponować głównego bohatera plakatu (milicjanta $^{6}$, robotnika, chłopa) bardzo często artyści decydowali się na użycie „żabiej perspektywy". Dzięki zastosowanej technice przedstawiane postaci jawiły się jako większe, zdawały się górować nad przechodniami mijającymi ich na ulicy. Artyści chętnie stosowali także uproszczenia,

${ }^{6}$ Przez długi okres walki zbrojne po stronie republikańskiej były prowadzone przez ochotników przystępujących do oddziałów milicji organizowanych przez główne partie polityczne Frontu Ludowego. W ramach tych formacji panowała względna demokracja i poszanowanie jednostki. Po raz pierwszy na frontach organizowano także kursy doszkalające dla niepiśmiennych milicjantów. Wojsko, a w szczególności rola zwykłego żołnierza $\mathrm{w}$ tej formacji, kojarzyło się lewicy $\mathrm{z}$ elementem starego reżimu, gdzie klasy wyższe ciemiężyły zwykłego chłopa i robotnika, traktując ich jak przysłowiowe „mięso armatnie". 
uciekając się do stereotypów o silnym charakterze społecznym. Odbiorca bez najmniejszego problemu potrafił rozpoznać na plakacie milicjanta, chłopa, robotnika, żołnierza faszystowskiego, przedstawicieli kleru, burżuazji itd., a wszystko dzięki umiejętnie zastosowanym atrybutom $(\mathrm{Gu}-$ bern 2008: 49). Pod tym względem plakaty doby hiszpańskiej wojny domowej charakteryzowała standaryzacja ikonograficzna. Ich projekt graficzny był bardzo często dobrze przemyślany i funkcjonalny. W celu nadania dynamiki przedstawianym czynom i postaciom artyści stosowali linie skośne. Przykładem może tu być projekt autorstwa Huertasa, na którym przebiegająca skośnie przez całą długość plakatu lufa armaty wydaje "ostatnią salwę symbolizującą zwycięstwo" (plakat 3). Zdarzały się przypadki, w których linie skośne miały na celu uwypuklenie żabiej perspektywy - doskonale obrazuje ten zabieg jeden z posterów Bardasano. Dzięki zastosowaniu tej techniki żołnierz republikański przedstawiony na środku plakatu zdaje się dominować nad wszystkim, wprowadzając atmosferę ładu i spokoju (plakat 4). Na niektórych afiszach można dopatrzyć się użycia linii skośnych wzajemnie się przekreślających. Przykładem może być tu plakat Ysacara Pokonamy ich wreszcie ${ }^{7}$, na którym hasło nałożone na postać żołnierza jest wytyczone w kierunku przeciwnym niż sama postać, potęgując tym samym efekt dynamizmu (plakat 5). Warto zauważyć, że stosowanie żabiej perspektywy nie ogranicza się jedynie do przedstawianych postaci, ale także przedmiotów (fabryk, kominów fabrycznych, czołgów, statków), które niejednokrotnie stają się głównymi bohaterami posteru. Nie należy zapominać także o technice coraz częściej stosowanej w tym czasie - a pozostającej nadal pewnego rodzaju novum - fotomontażu. Jest ona widoczna w pracach Renau, jednego z pierwszych artystów, wykorzystujących tę technikę w swych projektach jeszcze przed wybuchem wojny, ale zostaje użyta także w licznych realizacjach innych artystów. Trudno wyobrazić sobie selekcję plakatów z hiszpańskiej wojny domowej bez posteru autorstwa Renau. Z tego względu proponuję przyjrzeć się jego mało znanemu dziełu 1-szy Maja. Przejdziemy. Ofensywa na wszystkich frontach! ${ }^{8}$ - zawierającemu cechy fotomontażu będące znakiem firmowym twórcy (plakat 6).

\footnotetext{
${ }^{7} \mathrm{~W}$ oryginale ;Superémoslo aún!

${ }^{8} \mathrm{~W}$ oryginale: $1^{\circ}$ de Mayo. Pasaremos. ¡Ofensiva en todos los frentes! Hasło: „Przejdziemy” parafrazowało słynną frazę ukutą podczas oblężenia Madrytu w roku 1936 „Nie przejdą” („No pasarán”) przez samą La Pasionaria (Dolores Ibárruri Gómez), sławną działaczkę hiszpańską.
} 


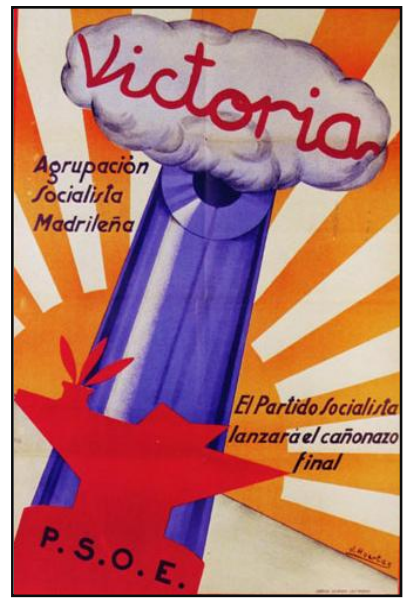

Plakat 3

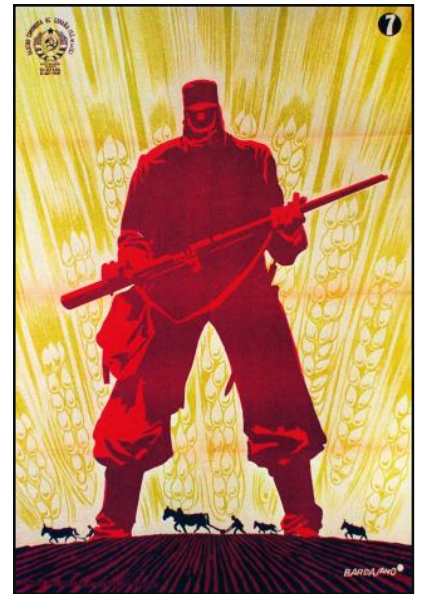

Plakat 4

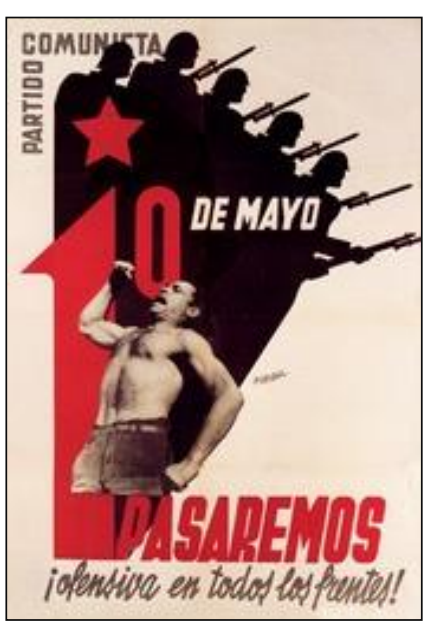

Plakat 6

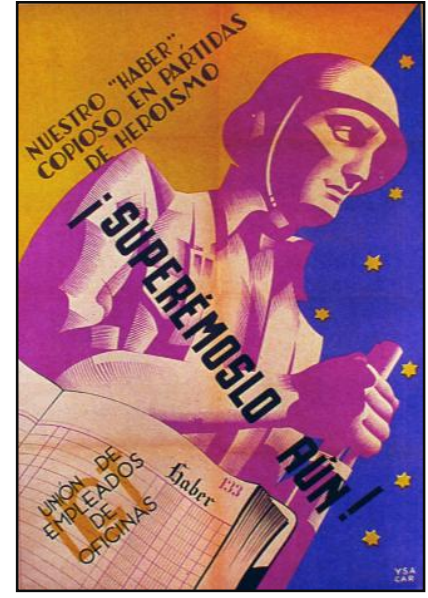

Plakat 5

\section{Style artystyczne}

W czasie, gdy wybuchła hiszpańska wojna domowa, w stolicach europejskich triumfy święciły surrealizm i kubizm, m. in. dzięki tak wybitnym Hiszpanom, jak Pablo Ruiz Picasso, Juan Miró czy Salvador Dalí. 
Z drugiej strony, trudno doszukać się tych prądów artystycznych w plakatach, które powstawały podczas konfliktu. Powodem były główne założenia rewolucji, zerwania ze „starym porządkiem”, w których sztuka tworzona była tylko na potrzeby klas wyższych, z pominięciem robotników i chłopów. Artyści zebrani w Związku Zawodowych Rysowników Katalonii uważali, że po raz pierwszy w dziejach Hiszpanii tworzą sztukę skierowaną do ludu. W tym celu należało zerwać z nurtami artystycznymi, które kojarzone były z burżuazją i stworzyć styl odpowiadający nowym wyzwaniom. Wsparto się na doświadczeniach sowieckich, chętnie odwołując się do realizmu będącego kwintesencją sztuki proletariatu. Wspomniany przeze mnie wcześniej Renau był pierwszym, który sformułował tezę o funkcji społecznej plakatu w swojej książce wydanej podczas trwania wojny Funkcja plakatu reklamowego' ${ }^{9}$.

Plakat, ze względu na swoją zasadniczą naturę i definitywne wyzwolenie się z niewoli kapitalizmu, może i powinien być potężną dźwignią nowego realizmu w swojej misji przekształcenia warunków w porządku historycznym i społecznym, dla stworzenia Nowej Hiszpanii. Jego podstawowym i natychmiastowym celem winno być pobudzanie rozwoju nowego człowieka, który wyłania się z okopów walki antyfaszystowskiej, poprzez bodziec emocjonalny sztuki wyższej o zawartości humanistycznej (Julian Gonzalez 1993: 130).

Jako że plakaty były kierowane do ludu, tworzono je w sposób bezpośredni i prosty $\mathrm{w}$ odbiorze - realizm $\mathrm{w}$ tym przypadku całkowicie spełniał swoje zadanie. André Gide na Kongresie Pisarzy w roku 1937 powiedział: "Sztuka w momencie zerwania kontaktu z rzeczywistością i życiem zamienia się $\mathrm{w}$ sztuczną. To zawsze $\mathrm{w}$ podstawie, $\mathrm{w}$ ziemi i w ludzie sztuka odzyskuje siły i się odnawia" (Julian Gonzalez 1993: 130).

Obok realizmu nurtem, do którego bardzo chętnie się odwoływano, był ekspresjonizm. Jako styl artystyczny, który pozwalał na przedstawienie emocji, o wiele łatwiej ekscytował i zwracał uwagę odbiorców, niż rzeczowy, wyzuty z uczuć realizm. Nurt ten dawał możliwość przedstawienia rzeczywistości, ukazując jej stronę dramatyczną. Doświadczenia duchowe i emocjonalne brały tu górę nad percepcją analityczną. $W$ tym przypadku, aby osiągnąć zamierzony cel, artyści posługiwali się deformacją zygzakiem, niespokojną linia, wyrazistym kolorem (Julian Gonzalez 1993: 130).

${ }^{9}$ W oryginale: Función del cartel publicitario (1937). 
Obok plakatów realistycznych istniała także duża liczba posterów satyrycznych, w których karykatura odgrywała naczelną rolę. Ich rodowodu bez wątpienia należy dopatrywać się w twórczości Władimira Majakowskiego dla ROSTA ${ }^{10}$. Jednocześnie nie można zapomnieć o wielkim malarzu hiszpańskim, tworzącym na przełomie wieków XVIII i XIX - Goi - i jego bezprecedensowych dokonaniach na tym polu. Karykatura w omawianym przez nas okresie była stosowana wyłącznie wobec nieprzyjaciela (Julian Gonzalez 1993: 132). Artysta tworzył karykaturę wybierając konkretną osobę, a następnie za pomocą deformacji bądź symboliki przedstawiał jej charakterystyczne cechy psychiczne i fizyczne, odsłaniając je przed oczami odbiorców. Twarz przedstawiana była w sposób maksymalnie uproszczony, tak aby móc stworzyć portret archetypowy, łatwo identyfikowany przez „publikę”. Świetnym i nietuzinkowym przykładem takiej karykatury jest plakat namalowany przez Cañavete Generalísimo ukazujący generała Franco w konwencji bajkowej. $Z$ jednej strony autor narysował generała jako króla obwieszonego medalami. Wyraz twarzy przedstawionej postaci, dosiadany konik, który przypomina zabawkę dla dzieci i fruwający nieopodal motylek nadają osobie generała aspekt zniewieścienia i niemożności działania. Z drugiej strony $\mathrm{z}$ atmosferą sielanki kłóci się maczuga, którą Franco trzyma nad swoją głowa swastyka faszystowska wypalona na zadzie dosiadanego rumaka, płaczące kaktusy o ludzkich twarzach oraz bomby spadające z chmur (plakat 7).

Innym sposobem tworzenia karykatury było przedstawianie postaci w sposób stereotypowy. Każda z nich reprezentowała grupę społeczną wywodzącą się ze "starego porządku”, czyli kler, wojsko i burżuazję. Świetnym przykładem plakatu ukazującego powyżej wymienione grupy społeczne jest projekt autorstwa Pedrero o tytule El Generalísimo (plakat 8).

Dyskusje ideologiczne dotyczące wyższość realizmu nad ekspresjonizmem czy też krytyki surrealizmu zapalały umysły artystów doby rewolucji, jednakże nie miały pełnego przełożenia na rzeczywistość. $W$ istocie

${ }^{10}$ ROSTA (Rosyjska Agencja Telegraficzna) - była to Państwowa Agencja Informacyjna działającą w Rosji Sowieckiej w latach 1918-1935. Na jej zamówienie Władimir Majakowski stworzył serię plakatów politycznych o charakterze satyrycznym, które zazwyczaj umieszczane były w oknach, stąd ich nazwa "okna Rosta". Afisze Majakowskiego stylistyką nawiązywały do rosyjskich tradycyjnych form litograficznych, takich jak lubok i rayok. 


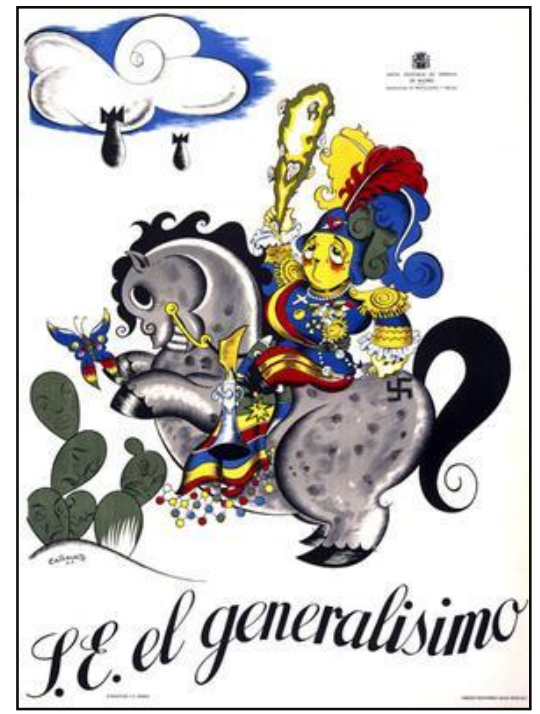

Plakat 7

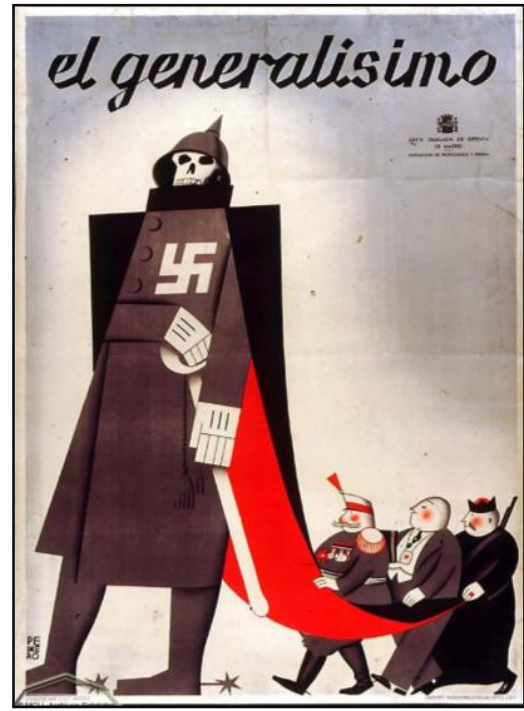

Plakat 8

styl, w jakim tworzono plakaty podczas wojny domowej, możemy scharakteryzować jako eklektyczny. Dominował w nim realizm polityczny, ale równie mocno zauważalne były ekspresjonizm, naturalizm, elementy dadaizmu i postkubizmu, jednym słowem był to trudny do scharakteryzowania eklektyzm estetyczny (Grimau 1979: 45-58).

\section{Tematyka plakatów}

Wszystkie plakaty republikańskie stworzone w czasie wojny można scharakteryzować jako skierowane do ludności cywilnej przebywającej na tyłach frontu. Przywołując klasyfikację tematyczną dokonaną przez Inmaculadę Julián González, możemy wyróżnić postery: przeciwko faszyzmowi, o milicji i poborze, o regularnym wojsku ludowym, z mapa$\mathrm{mi}$, o solidarności, o produkcji na tyłach frontu, bombardowaniach, przeciwko prostytucji, o pomocy dla Madrytu i Kraju Basków, pomocy dla uchodźców, przeciwko inwazji obcych mocarstw (Niemiec i Włoch), o robotach publicznych, o piątej kolumnie, a także kampaniach kulturowych i rocznicach. 
Każdy z powyższych tematów można by zilustrować dużą liczbą plakatów o wysokiej wartości artystycznej, a i tak stanowiłyby one jedynie fragment wielkiej różnorodności stworzonych projektów. W tym rozdziale, dysponując ograniczonym zasadami publikacji miejscem, pragnę zaprezentować dwa, moim zdaniem, szczególnie interesujące przykłady.

Pierwszym z nich jest plakat autorstwa Arteche stworzony w pierwszym miesiącu konfliktu. Miał on na celu zmobilizowanie młodych ludzi do zaciągnięcia się do oddziałów milicji, które w tym czasie ruszały na Saragossę opanowaną przez siły nacjonalistyczne. Do czynu zbrojnego zachęca, inaczej niż działo się to w Wielkiej Brytanii, Stanach Zjednoczonych czy Rosji Sowieckiej, młoda dziewczyna z bronią w ręku, ubrana w kombinezon robotniczy. Był to wizerunek chętnie używany w plakatach powstających w pierwszym etapie konfliktu. Kobieta - milicjantka, w sławnym niebieskim kombinezonie ${ }^{11}$, stała się symbolem rewolucji, rozpalając umysły współczesnych i zachęcając ludność cywilną do działania na rzecz wspólnej sprawy, jaką była wojna z faszyzmem ${ }^{12}$ (plakat 9).

Kolejny plakat, będący makabrycznym fotomontażem autorstwa Péreza Contela, nawiązuje do bombardowań głównych miast Hiszpanii, pozostających w rękach republikanów. Przedstawione na zdjęciach zwłoki madryckich dzieci, które poniosły śmierć w wyniku nalotów nacjonalistów, miały na celu nakłonienie do działania niezdecydowanych. Napis na afiszu głosi: „Mordercy! Kto widząc to nie chwyta za broń, aby zgładzić destrukcyjny faszyzm?"13 (plakat 10).

Plakatem, który świetnie oddaje zmianę polityki rządu republikańskiego w kwestii kobiet i ich roli w trwającym konflikcie zbrojnym, jest projekt autorstwa Rivero Gila. Rysownik przedstawia śmiertelne za grożenie,

${ }^{11}$ Kombinezony robotnicze oraz furażerki stały się hitem mody ulicznej pierwszych dni wojny. Strój pracownika fizycznego, taki sam dla kobiet i mężczyzn, odnosił się do ideologicznego zrównania ich $\mathrm{w}$ prawach, a także zlikwidowania różnic społecznych pomiędzy klasami, które do tej pory zaznaczały się najwidoczniej poprzez strój.

${ }^{12}$ Kobiety podczas trwania II Republiki doczekały się rozwiązań prawnych (jednych z bardziej reformatorskich w tym czasie w Europie), które w wyraźny sposób poprawiły ich status w społeczeństwie. Przegrana wojna oznaczała dla nich nie tylko brak wolności politycznych, ale zaprzepaszczenie wszystkich dokonań w sprawie zrównania ich w prawach z mężczyznami i powrót do roli pań domu. $Z$ tego powodu kobiety bardzo aktywnie włączyły się we wszelkie działania wyznaczane im przez rząd republikański wstępując do oddziałów milicji, a także pracując na tyłach frontu, piorąc, dostarczając pocztę, pracując na roli, $\mathrm{w}$ fabrykach, szyjąc mundury, płaszcze itd.

${ }^{13} \mathrm{~W}$ oryginale: „„Asesinos! ¿Quien al ver esto, no empuña un fusil para aplastar al fascismo destructor?" 


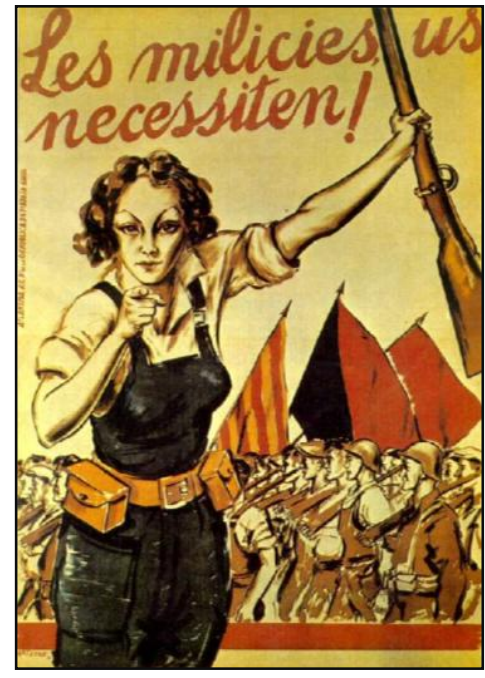

Plakat 9

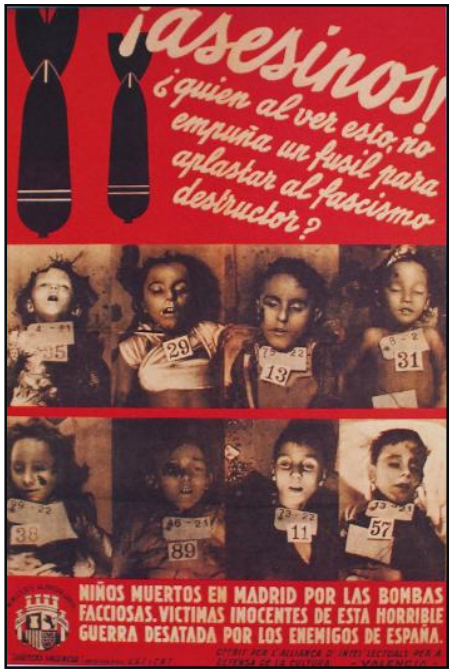

Plakat 10

które czyha na mężczyzn ze strony prostytuujących się kobiet. Mowa tu oczywiście o groźnych chorobach wenerycznych, które stały się pretekstem do wycofania kobiet $\mathrm{z}$ frontów, na których walczyły ramię w ramię z mężczyznami. Plakat, dzięki interesującej kompozycji artystycznej oraz nasyconym kolorom, wyraziście ukazuje podjęty temat (plakat 11).

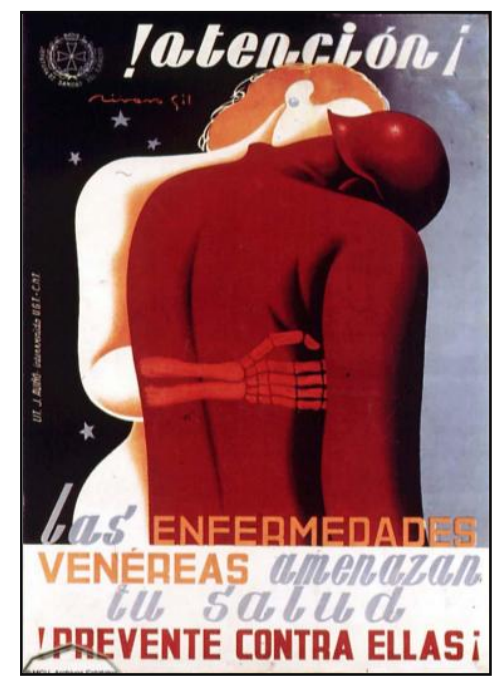

Plakat 11

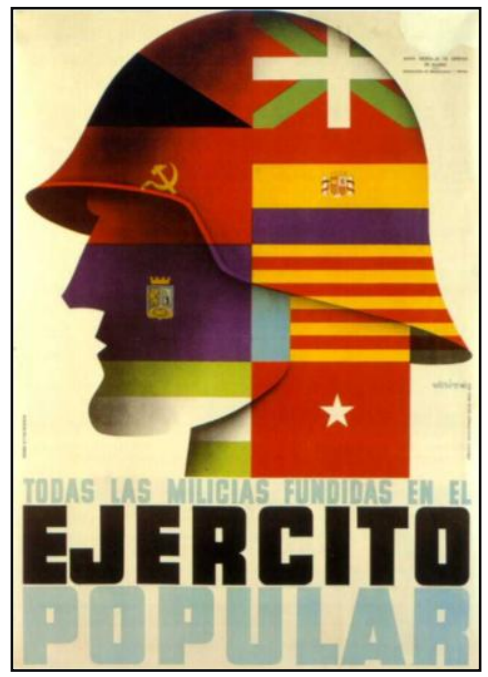

Plakat 12 
Ostatnim plakatem republikańskim, który chciałabym zaprezentować, jest jeden z najwybitniejszych posterów, jakie powstały podczas trwania wojny domowej. Autorem plakatu, który uzasadnia decyzję o połączeniu wszystkich milicji w jedną regularną Armię Ludowa, jest Melendreras ${ }^{14}$. Klarowna i genialnie przemyślana została kompozycja posteru, w której na centralnym miejscu znajduje się ikonograficznie przedstawiona głowa żołnierza republikańskiego, skupiająca w sobie wszystkie symbole i flagi frakcji politycznych, wchodzących w skład Frontu Ludowego. Pod spodem został umieszczony napis „Wszystkie milicje zespolone w Wojsku Ludowym" (plakat 12).

\section{Strona nacjonalistyczna}

Próba analizy plakatów frankistowskich przysparza wielu problemów. Po pierwsze jest to temat niechętnie podnoszony przez historyków i badaczy, a przez to praktycznie dziewiczy ${ }^{15}$. Ze szczątkowej liczby publikacji na ten temat możemy dowiedzieć się, że w porównaniu ze stroną republikańską plakaty frankistowskie praktycznie nie istniały. Czytając krótki rozdział autorstwa Carmen Grimau, poświęcony temu zagadnieniu, dowiadujemy się, że o ile Barcelona i terytorium zajmowane przez republikanów tonęło $\mathrm{w}$ kolorowych afiszach, o tyle po stronie nacjonalistycznej panowała cisza. Sama autorka podkreśla, że plakat frankistowski można określić tylko w kategoriach jego „nieistnienia”. Postanowiłam w miarę możliwości zweryfikować ten pogląd.

Rzeczywiście, w szerokim wachlarzu środków propagandowych, jakimi dysponowała dyktatura nacjonalistyczna, plakat zajmował pozycję marginalną. Może to dziwić, biorąc pod uwagę produkcję afiszy, jaka

${ }^{14} \mathrm{O}$ ile w pierwszym okresie trwania wojny domowej oddziały milicji świetnie zdały swój egzamin, nie dopuszczając do przejęcia przez siły nacjonalistyczne dużych ośrodków miejskich, takich jak Barcelona, Madryt, Walencja itd., o tyle w walce na froncie ponosiły duże straty $\mathrm{w}$ starciu $\mathrm{z}$ dobrze zorganizowaną armią generała Franco. $\mathrm{Z}$ tego powodu powstała idea połączenia wszystkich oddziałów milicji w regularne Wojsko Ludowe.

${ }^{15}$ We współczesnej Hiszpanii zajmowanie się epoką frankistowską jest dalece niepoprawne politycznie. Triumfy święci natomiast spisywanie historii opowiedzianej przez „wielkich przegranych", czyli republikanów. 
rozwijała się $\mathrm{w}$ tym czasie na dużą skalę we Włoszech faszystowskich czy Niemczech nazistowskich. Praktycznie od czasów I wojny światowej każdy konflikt zbrojny pociągał za sobą produkcję plakatów mających na celu mobilizację społeczeństwa. W przypadku Hiszpanii nie mogło być inaczej. Niezależnie od opinii wielu specjalistów należy zaznaczyć, że plakaty powstawały po obu stronach frontu. Jednakże ich popularność po stronie nacjonalistycznej w żadnej mierze nie może być porównywana $\mathrm{z}$ tą po stronie republikańskiej.

Jak już wcześniej wspomniałam, powyższa sytuacja po części została spowodowana opanowaniem przez Narodowców tzw. obszaru rolniczego. Cały przemysł graficzny znajdował się więc w tym czasie $\mathrm{w}$ rękach Republikanów, a miasta zajęte przez generała Franco (np. Sewilla, Valladolid czy Burgos) nie miały takich tradycji w produkcji plakatów, jak Walencja, Barcelona czy Madryt. Potwierdzenie tej tezy może stanowić fakt, iż większość frankistowskich afiszów politycznych, a z pewnością te najbardziej udane, pojawiła się dopiero po zajęciu przez nacjonalistów Barcelony, wraz z końcem wojny. W tej sytuacji, korzystając z wydawnictw katalońskich i współpracując z artystami, którzy postanowili pozostać $\mathrm{w}$ mieście i przejść na stronę frankistów, stworzono kilka ciekawych plakatów. Jednym z najwybitniejszych powstałych w tym czasie projektów był afisz Flosa (autor ten przez cały okres wojny tworzył na potrzeby strony republikańskiej). Plakat ten został wykonany, aby uczcić koniec konfliktu zbrojnego. Porusza temat kombatanta wojennego, który zwycięsko powrócił z wojny i wymaga teraz od cywili podjęcia wysiłku budowania Nowej Hiszpanii. Od strony graficznej plakat jest świetnie przemyślany. Na bluzie wojskowej widnieje medal, świadczący o męstwie właściciela, a na jednym z rękawów trzy trójkąty, które symbolizują trzykrotne odniesienie ran na froncie. Pas i hełm, pozostawione na krześle, oznaczają koniec wojny, ale widniejące obok strzały Falangi ${ }^{16}$ udekorowane różami przypominają o pracy społecznej w ramach narodowego syndykalizmu, która miała się właśnie rozpocząć (plakat 13).

16 Falanga Hiszpańska, Falange Española, hiszpańska partia polityczna, założona w roku 1933 przez J. A. Primo de Riverę; dążyła do utworzenia państwa korporacyjnego i autorytarnego; w 1937 r. podporządkowana generałowi F. Franco i połączona z karlistami, jedyna legalna partia frankistowskiej Hiszpanii; w roku 1957 przekształcona w ruch polityczny (Ruch Narodowy, rozwiązany w 1977 r.). 


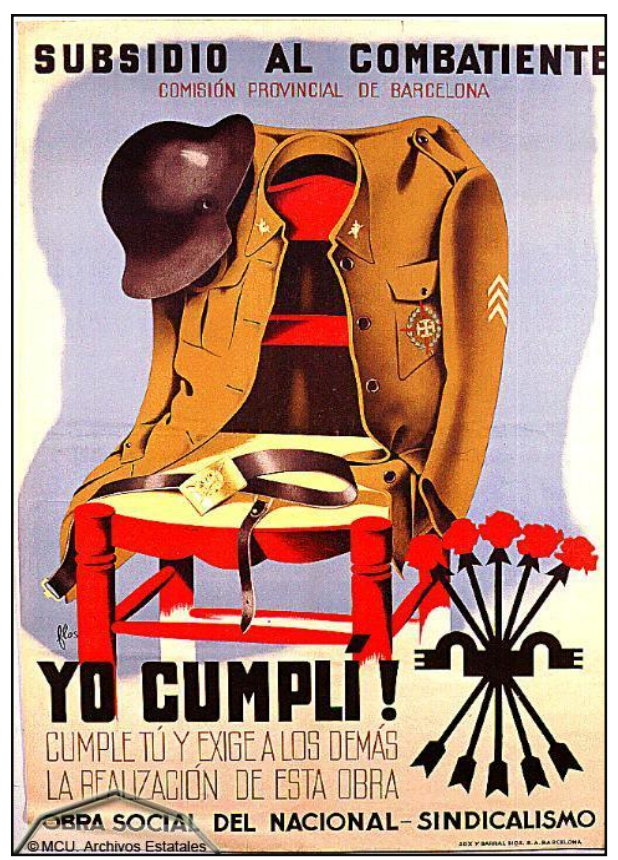

Plakat 13

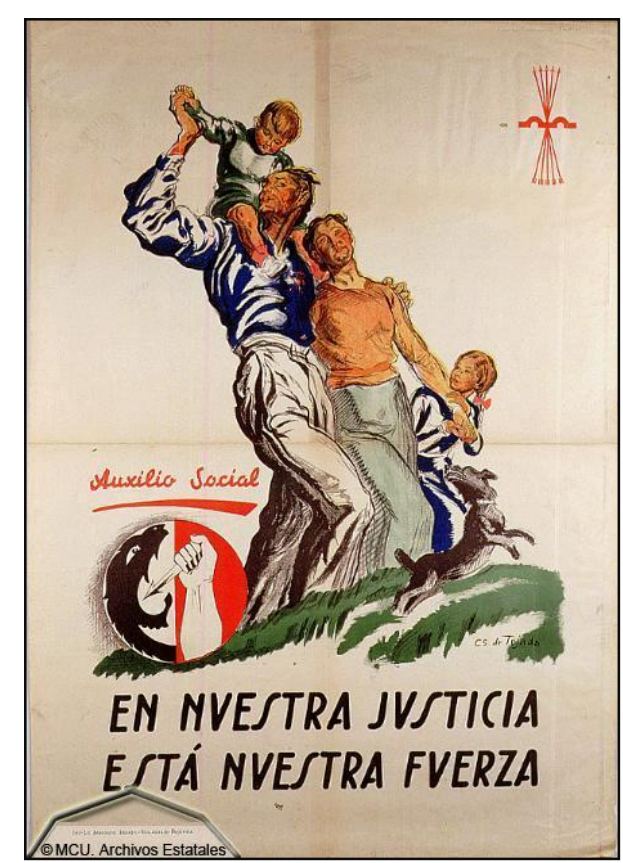

Plakat 14

Z drugiej strony, chwaląc za wysoki poziom artystów republikańskich, nie można zapominać, że reżim frankistowski także miał wybitnych rysowników w swojej służbie. Bodaj najwybitniejszym w tym kręgu był Carlos Sáenz de Tejeda. Jego kompozycje symboliczno-alegoryczne stały się typowe dla okresu powojennego. Był on reprezentantem stylu rysunkowego $\mathrm{w}$ plakacie nacjonalistycznym. W okresie powojennym zilustrował 36-tomową Historię Hiszpańskiej Krucjaty, która przez wiele lat była oficjalną wykładnią wiedzy o wojnie domowej. Wraz z José Caballero, Teodoro i Álvaro Delgado tworzył także ilustracje do oficjalnego pisma Falangi - „Vértice”, które stanowiło największe osiągnięcie intelektualne doby wojny domowej po stronie frankistowskiej. Na potrzeby tej publikacji wybrałam jeden $\mathrm{z}$ najbardziej typowych dla jego twórczości plakatów pod tytułem $W$ naszej sprawiedliwości jest nasza siła ${ }^{17}$. Afisz mający charakter alegorycznego obrazka przedstawia szczęśliwą rodzinę kroczącą w świetlaną przyszłość (plakat 14).

${ }^{17} \mathrm{~W}$ oryginale: „En nuestra justicia está nuestra fuerza”. 


\section{Centralizacja władzy}

Jak sugeruje autor książki El color de la guerra - The color of War. Spanish civil war. 1936-39 Jordi Carulla, być może eksplozja produkcji plakatów, która dokonała się po stronie republikańskiej, była dla nacjonalistów potwierdzeniem tezy o decentralizacji, jakiej ulegała lewica, co stanowiło $\mathrm{w}$ ich oczach element zagrożenia i destabilizacji kraju (Carulla, Carulla 2000: 5). Franco, aby uniknąć tego problemu, doprowadził do centralizacji władzy i zrzeszenia licznych prawicowych ugrupowań i frakcji politycznych $w$ jeden organizm partyjny. Nie zabronił natomiast produkcji plakatów o wydźwięku czysto falangistowskim czy karlistowskim, tworząc tym samym ułudę pluralizmu politycznego.

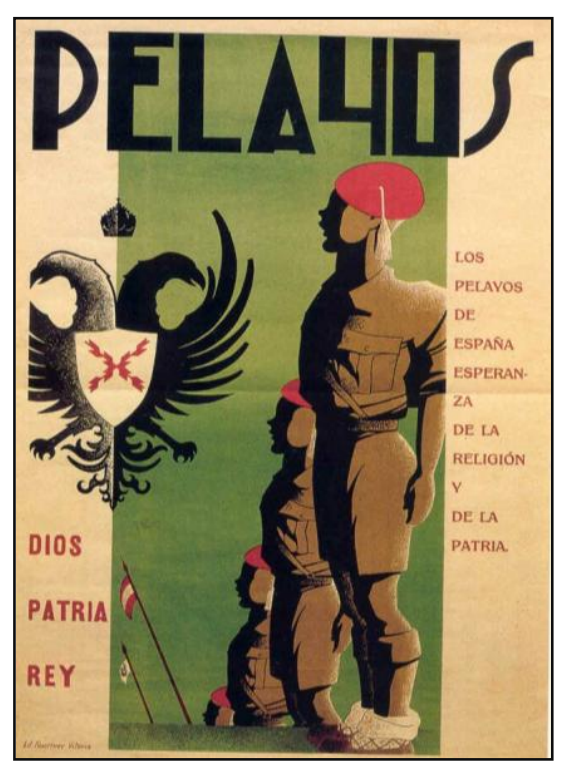

Plakat 15

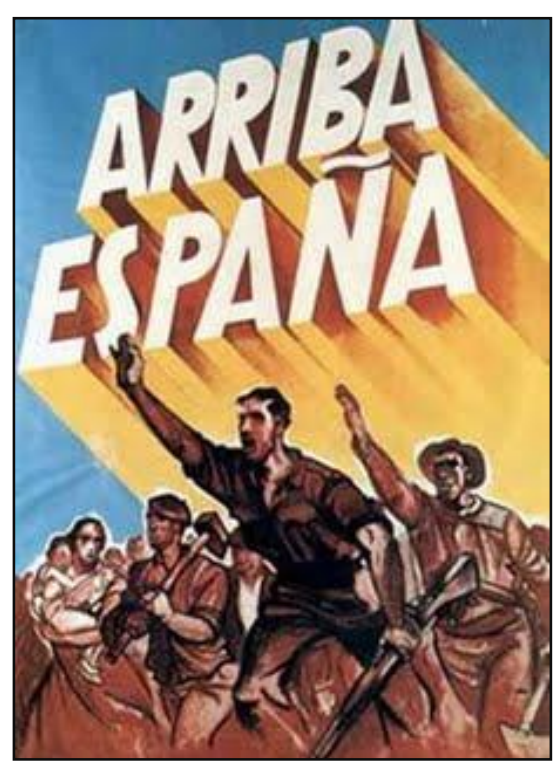

Plakat 16

Plakat, który w tym miejscu postanowiłam przedstawić, jest o tyle oryginalny, że nawiązuje do jedynego ruchu o charakterze masowym, szczególnie popularnego w regionie Nawarry, który wchodził w skład panoramy politycznej strony frankistowskiej. Mowa tu o karlistach, a w tym konkretnym przypadku o ich formacji dziecięcej - Pelayos. Afisz symbolizuje przede wszystkim tradycje polityczną poprzez dość schema- 
tyczne potraktowanie tematu, jednocześnie nie przejawia tak często nadużywanego w plakatach nacjonalistycznych liryzmu manierystycznego ${ }^{18}$. Nieodzownym symbolem towarzyszącym temu ugrupowaniu był herb królewski Burbonów, których karliści pragnęli przywrócić na tron Hiszpanii (plakat 15).

Plakaty nawiązujące treścią do paramilitarnej formacji Falangi były bardzo popularne, ja na potrzeby dokonywanej analizy wybrałam dwa szczególnie interesujące. Na afiszu stworzonym przez nieznanego autora możemy zobaczyć żołnierzy, chłopów i robotników idących ramię w ramię $\mathrm{z}$ falangistą podnoszącym rękę ku górze $\mathrm{w}$ charakterze powitania na modłę Starożytnego Rzymu. Był to gest typowy dla systemów totalitarnych, któremu towarzyszył okrzyk „W górę Hiszpania!”, będący jednocześnie hasłem przewodnim tego i wielu innych plakatów. Afisz nawiązywał do ruchu masowego, jaki chciała stworzyć Falanga (wprowadzając nową formę tytułowania swoich członków per "towarzyszu", niebieskie koszule z zakasanymi rękawami, czerwono-czarne flagi, przypominające barwy anarchistów), który pozostał jedynie pobożnym życzeniem. Powyższe cechy charakterystyczne dla tego ruchu, wraz z nowym pozdrowieniem, możemy zaobserwować na przedstawionym plakacie (plakat 16).

Natomiast jednym z plakatów nawiązujących do ideologii wielkiego teoretyka narodowego syndykalizmu i założyciela Falangi, José Antonio Primo de Rivery ${ }^{19}$, był afisz autorstwa J. Cabanasa. Wizerunek ręki podnoszącej do góry karabin stał się już od czasów rewolucji bolszewickiej symbolem walki zbrojnej, równie często i chętnie wykorzystywanym po obu stronach barykady. Hasło plakatu „Ojczyzna, chleb i sprawiedliwość" 20 było najbardziej rozpropagowanym spośród idei ruchu falangistów (plakat 17).

Wojsko pod dowództwem generała Franco, przy wsparciu Kościoła katolickiego, stworzyło solidny system wartości moralnych adresowany przede wszystkim do ludności wiejskiej. $Z$ drugiej strony używane przez nacjonalistów symbole, hasła i rytuały nawiązywały do święcących triumfy po I wojnie światowej w Europie systemów autorytarnych. Sytuacja, w której doszło do wymuszonego połączenia się wszystkich sił

${ }^{18}$ Liryzm manierystyczny - nad wyraz wybujała, przesadzona uczuciowość i nastrojowość, przejawiająca się $\mathrm{w}$ dziełach sztuki.

${ }^{19}$ José Antonio Primo de Rivera, prawnik, założyciel i lider Falangi, jedyny cywilny przywódca nacjonalistów. Uważa się, że gdyby nie jego śmierć w pierwszych dniach po nieudanych przewrocie wojskowym do wojny domowej nigdy by nie doszło.

${ }^{20}$ W oryginale: „La Patria, el pan y la justicia”. 


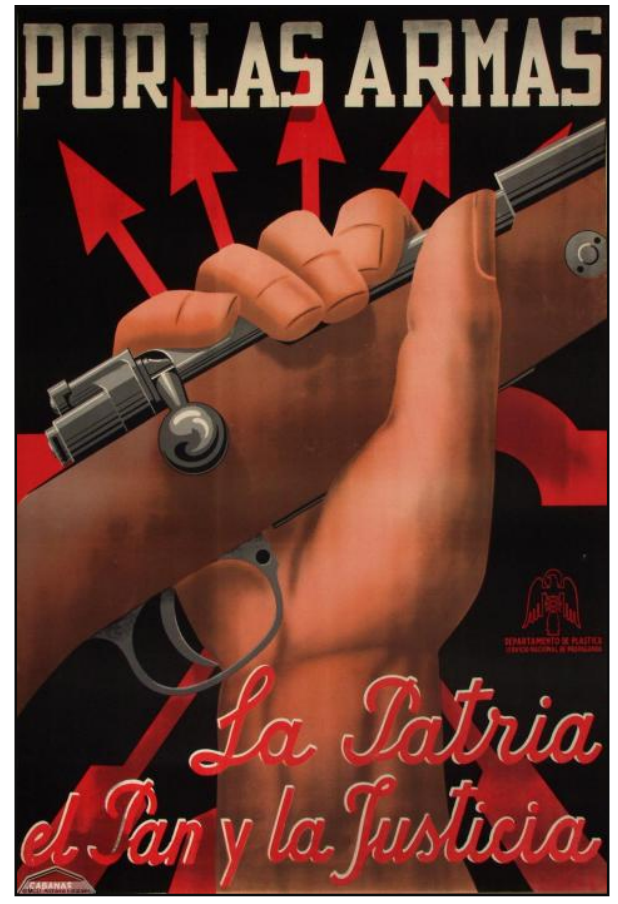

Plakat 17

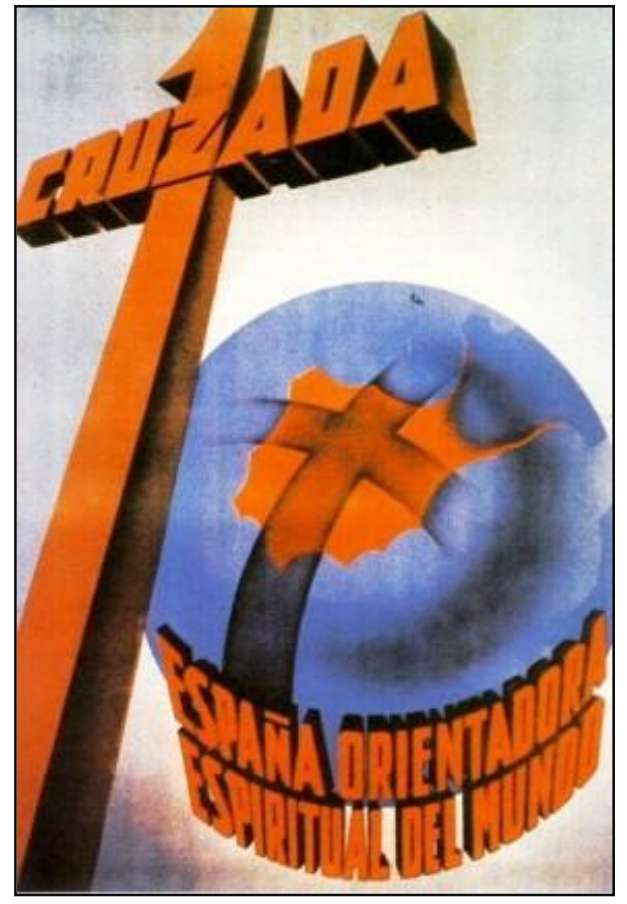

Plakat 18

politycznych w jedną partię, doprowadziła w konsekwencji do zagłuszenia tendencji faszystowskich i przewagi konserwatystów. Coraz silniejsza pozycja Kościoła katolickiego spowodowała ustabilizowanie powyższej sytuacji. Generał Franco zyskał poparcie kleru, nazywając trwający konflikt militarny krucjata, a republikanów mianem niewiernych. Powyższe tendencje miały ogromny wpływ na tworzone $\mathrm{w}$ tym czasie plakaty. Afisz frankistowski był nasycony symboliką konserwatywna, mającą charakter narodowo-katolicki, faszystowski lub totalitarny. Temat krucjaty łączył się w nim z hiszpańskim mitem imperialnym i rolą Hiszpanii jako światowej orędowniczki religijnej. Ze względu na barbarzyństwa, jakich dopuszczali się republikanie (palenie kościołów, gwałcenie zakonnic, zabijanie księży) generał Franco stawiał problem uratowania Kościoła katolickiego na pierwszym miejscu i traktował go jako główny powód przewrotu. Poruszane powyżej kwestie zostały zilustrowane w sposób niezwykle klarowny na plakacie stworzonym przez Państwowy Urząd Propagandy w Barcelonie w ostatnich dniach wojny (plakat 18). 


\section{Państwowy Urząd Propagandy}

Spośród szerokiego wachlarza środków propagandy, wykorzystywanych w tym czasie przez przywódców państw autorytarnych, Generalísimo najbardziej upodobał sobie przekaz radiowy. Z drugiej strony, propaganda Franco o wiele silniej nastawiona była na spektakularne czyny niż słowa. $Z$ tego powodu ogromne sumy przeznaczano na pomoc dla ludności cywilnej - rozdawano żywność, odzież i koce, organizowano stołówki, ochronki dla sierot wojennych w ramach tzw. Pomocy Społecznej (Auxilio Social).

Po miesiącach dezorganizacji, na początku roku 1938, aparat propagandy został zlokalizowany w Kwaterze Głównej w Burgos, a na jego czele stanęli dwaj młodzi falangiści Dioniso Ridruejo i Antonio Tovar. Z tego tandemu szczególnie Ridruejo posiadał bardzo dużą wiedzę na temat propagandy tworzonej w europejskich państwach autorytarnych Niemczech i Włoszech (Grimau 1979: 229-232). Pomimo swoich niezaprzeczalnych kwalifikacji nie miał on jednak w istocie wpływu na dobór środków agitacji i ich funkcjonowanie. Osobiste zaangażowanie Franco w sprawy dotyczące propagandy sprawiło, że tworzący plakaty artyści dostawali bardzo szczegółowe instrukcje dotyczące zarówno hasła, jak i kompozycji projektu. Pociągało to za sobą kilka konsekwencji. Po pierwsze, ścisła ingerencja głównodowodzącego w kompozycję plakatów zaniżała ich walor artystyczny. Ze względu na odgórne dyrektywy, powstające afisze były tworzone w sposób bardzo tradycyjny, nie znajdziemy w nich rysu realizmu czy naturalizmu socjalnego. Cechowało je także przeładowanie symbolika, która została wprowadzona na potrzeby nowej ideologii na początku trwania konfliktu ${ }^{21}$. Starano się tym samym zatuszować fakt dokonania przewrotu wojskowego. Nowy reżim wprowadził symbole nawiązujące do świetności Hiszpanii w czasach minionych. Z tego powodu na plakatach pojawiał się krzyż św. Andrzeja, orzeł św. Jana, a łuk ze strzałami został zapożyczony przez falangistów z pełnych chwały czasów Królów Katolickich. Nawet symbol organizacji charytatywnej „Pomoc Społeczna” przedstawiał smoka ugodzonego ostrzem, co miało nawiązywać do postaci św. Jerzego i jego walki ze złem.

${ }^{21} \mathrm{~W}$ pierwszych dniach konfliktu strona narodowa nadal używała flagi i symboli II Republiki. To ulica spontanicznie powróciła do symboli używanych w Hiszpanii za czasów monarchii, co szybko podchwycił Franco. 
Powyższą ikonografię można zaobserwować na każdym plakacie, który powstał po stronie nacjonalistycznej. Proponuję zapoznać się z dwoma afiszami stworzonymi na potrzeby frankistów po ich wkroczeniu do Barcelony. Miały one na celu uświadomienie ludności cywilnej, że „antyHiszpania" została pokonana. Do tego celu użyto afiszy przeładowanych symboliką frankistowska, z czytelnymi hasłami typu „Nadeszła Hiszpania”"22 czy też „Hiszpania zmartwychwstała”23. Obydwa plakaty, dzieła nieznanych autorów, pod względem artystycznym mają cechy dobrej kompozycji, z użyciem linii skośnych $\mathrm{w}$ celu zdynamizowania projektu oraz żabiej perspektywy, aby nadać przedstawionym figurom monumentalności. Użyto także żywych i kontrastujących kolorów. Symbole świadczące dobitnie o końcu wojny to białe gołębie w górnej części pierwszego z omawianych afiszy i figura zwycięstwa dominująca w drugiej kompozycji. Wszystkie te zabiegi służyły przyciągnięciu uwagi odbiorcy i sprawiły, że plakaty charakteryzują się wysokim poziomem artystycznym ${ }^{24}$ (plakat 19 i 20).

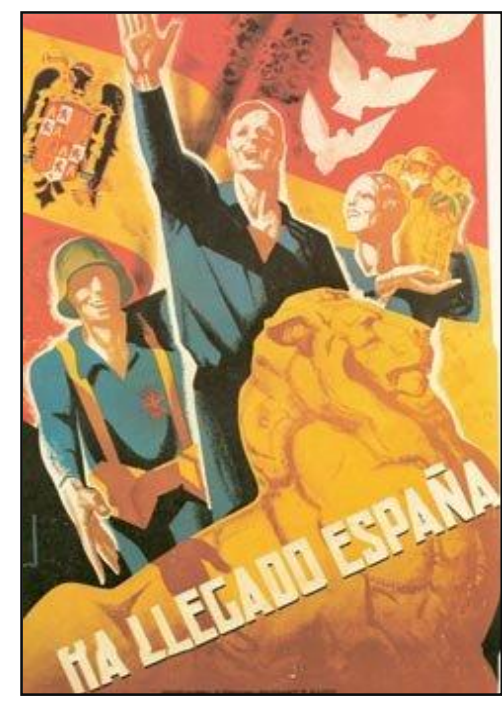

Plakat 19

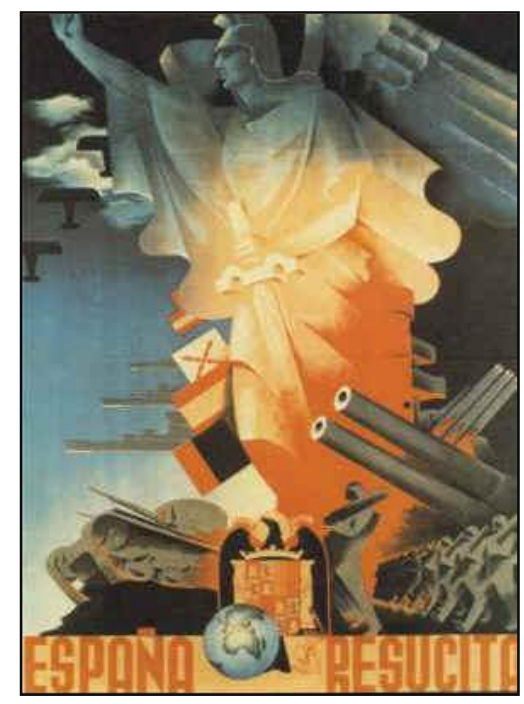

Plakat 20

22 W oryginale: „Ha llegado España!”

${ }^{23}$ W oryginale: „España resucita!”

${ }^{24}$ Dodać należy, że wszystkie napisy zamieszczano w języku kastylijskim, jako że użycie katalońskiego czy baskijskiego stało się po wojnie nielegalne w miejscach publicznych. 


\section{Tematyka plakatów i próba ich analizy}

Podobnie jak w przypadku plakatów republikańskich można przyjąć tezę, że wszystkie były skierowane do ludności cywilnej przebywającej na tyłach frontu w miastach i na wsiach. Tematyka plakatów miała przede wszystkim charakter ideologiczny. W związku z tym pojawiały się $\mathrm{w}$ formie graficznej, czasami przyozdobionej zdjęciem Franco lub symbolem Falangi, główne hasła frankizmu („Hiszpania jedna, wielka i wolna"; „W górę Hiszpania” itd.). Obok nich produkowano wiele plakatów-obrazków w stylu liryczno-alegorycznym, nawołujących do czynu patriotycznego. $W$ przypadku mężczyzn miał to być udział w walce, kobietom natomiast przypadała rola oczekiwania na nich $\mathrm{w}$ domu i szycia ciepłych ubrań na front. Istniało także gros afiszy przedstawiających sielankowe życie po wojnie w tzw. Nowej Hiszpanii, wolnej od głodu i biedy ${ }^{25}$. Niezależnie od powyżej wymienionych dwóch typów plakatu ideologizującego, istniał jeszcze trzeci, propagujący partie polityczne wchodzące w skład obozu nacjonalistycznego. Na wielu plakatach z tego okresu rozpoznamy bez trudu falangistów lub karlistów ruszających ochoczo na front bądź patrzących ufnie w przyszłość.

Drugim typem plakatu frankistowskiego był afisz o charakterze religijnym przedstawiający liczne oblicza Matki Boskiej (np. de la Cabeza, del Pilar) patronujące sprawie nacjonalistów lub anioła lecącego nad głowami idących na front żołnierzy, itd.

Trzecim rodzajem plakatu frankistowskiego, najsilniej propagowanym, był zaś portret generała Franco, w dużo mniejszym stopniu ideologa prawicy José Antonio. Jak stwierdziła Carmen Grimau:

Jedyne plakaty, które przetrwają podczas całej historii frankizmu, jedyne, które się opra, nieusuwalne wraz z przemijającym czasem politycznym, będą plakaty i portrety Franco (Grimau 1998: 273).

W celu poparcia tej tezy rozmawiałam z profesorem historii Juanem Blanco, który w późnych latach siedemdziesiątych studiował na Uniwersytecie w Salamance. Twierdził on, że na niektórych budynkach widoczne jeszcze były wówczas portrety Franco namalowane bezpośrednio na murach z powodu braku papieru, pochodzące z czasów wojny domowej.

${ }^{25}$ Dodać należy, że czasy powojenne w Hiszpanii, kiedy generał Franco z powodów politycznych musiał przystać na autarkię ekonomiczna, doprowadziły kraj do nędzy i głodu o rozmiarach niezaznanych nawet podczas wojny domowej. 
Forma przedstawienia generała nigdy nie ulegała zmianie. Był zawsze wyprostowany, jego wzrok zdawał się nieodgadniony, nigdy nie pokazywano całej jego sylwetki, koncentrując się raczej na popiersiu. Spowodowane to było jego wątła posturą i brakiem widocznych cech przywódczych, które sztab fachowców od propagandy musiał naprędce "tworzyćc. Ich rezultatem był fakt, iż Franco nie był znany przez obraz. Społeczeństwo poznawało go poprzez pryzmat walorów wcześniej wymyślonych i umiejętnie eksponowanych. Występował w niekończącej się liczbie ról, jako Franco wybawca, Franco dobry żołnierz, Franco genialny strateg, Franco dobry mąż i ojciec. Kochał też Hiszpanię jako żołnierz zakonnik (Grimau 1998: 285) miłością czystą i - jak głosiła propaganda odwzajemnioną. Jako przykład ilustrujący to zjawisko wybrałam plakat, który był najczęściej powielanym portretem Franco. Poster został wykonany po zakończeniu wojny i stanowił swoistą alegorię zwycięstwa. Ze względu na barokową wręcz formę silnie kontrastował $\mathrm{z}$ prostym w przekazie afiszem republikańskim. Pomimo iż mamy do czynienia ze wspaniałym obrazem, w swym przepychu nawiązującym do dzieł malarstwa panoramicznego wieku XIX, i przedstawieniem Franco niczym wodza wielkiej zwycięskiej armii, jako plakat nie spełniał swoich funkcji. Zapowiadał natomiast kult jednostki, który rozpoczął się w Hiszpanii po zakończeniu wojny domowej.

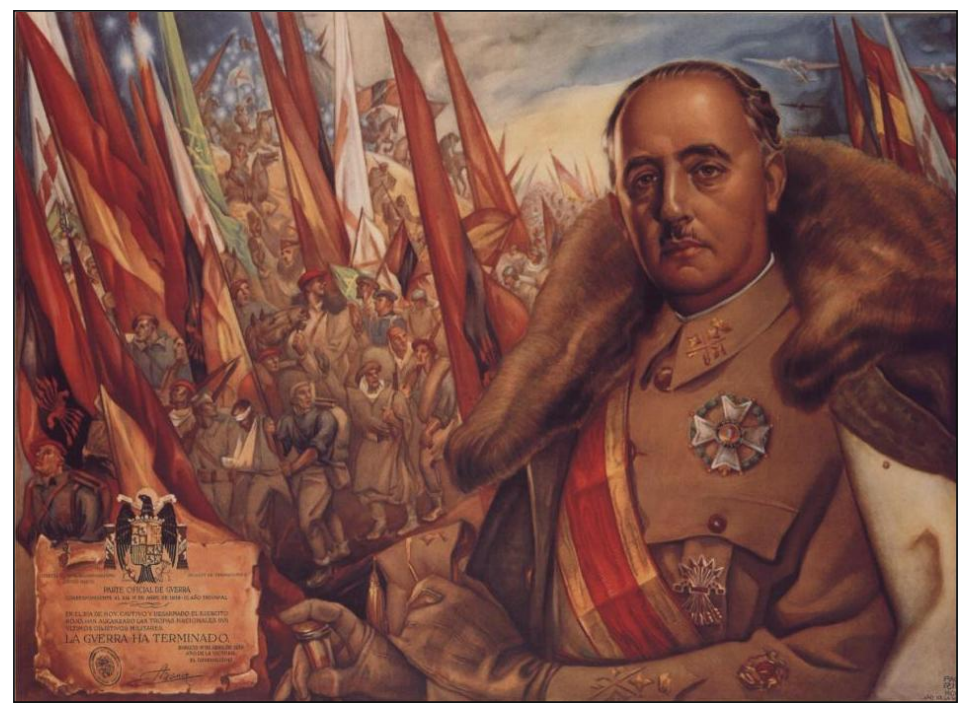

Plakat 21 
Przechodząc do analizy plakatów stworzonych w obozie nacjonalistycznym, po raz kolejny należy podkreślić, że ich liczba była o wiele mniejsza niż tych tworzonych po stronie republikańskiej. Przeważająca część nie miała większego waloru artystycznego. Formy kompozycyjne zastosowane przy ich tworzeniu cechowała tradycyjność. Bardzo rzadko wykorzystywano środki wyrazu, które miały na celu nawiązanie szybkiego kontaktu z odbiorca - mowa tu o klarownej formie, kolorze, dobrej kompozycji. W wielu przypadkach funkcję plakatu spełniał tradycyjny rysunek rodziny, generała Franco czy José Antonio, wykonany w sposób liryczno-manierystyczny. Plakaty dosłownie przeładowywane były przedstawieniem herbów, flag i insygnii - symboli Nowego Państwa. Często, podobnie jak w przypadku republikanów, uciekano się do karykatury znanych postaci z życia politycznego lewicy bądź posługiwano się stereotypowym przedstawieniem komunisty. $Z$ drugiej strony nie można utrzymywać, że pośród plakatów zaprojektowanych przez nacjonalistów nie było bardzo dobrych projektów, co, mam nadzieję, poświadczają wybrane przeze mnie przykłady.

\section{W miejsce podsumowania}

Próbując dokonać porównania plakatów tworzonych po obu stronach barykady, mimo wielu różnic, możemy wyłowić kilka aspektów, które je łączyły. Zarówno republikanie, jak i nacjonaliści chętnie przesycali swoje kompozycje symbolika, flagami i herbami. Fakt ten jest potwierdzeniem tezy o pierwszoplanowej roli ideologii w tym konflikcie. Obie strony uciekały się do ikonograficznych przedstawień faszyzmu i komunizmu jako węży, smoków, potworów lub robactwa i bakterii, które należy usunąć jako główne zagrożenie i zło. Poprzez plakat próbowano przestraszyć ludność cywilną zagrożeniem, jakie niosła ze sobą obca ideologia. Stąd jako przestrogę przed faszyzmem przedstawiano zdjęcia dzieci zabitych w wyniku bombardowań, a komunizm prezentowano jako wszystkopożerającego giganta ${ }^{26}$. Z drugiej strony ideologię własną za wszelką cenę chciano ukazać jako tę, która niesie pomoc i pragnie pokoju. Ponadto zarówno strona republikańska, jak i frankistowska

${ }^{26} \mathrm{~W}$ tym wypadku było to bezpośrednie nawiązanie do twórczości Francisco de Goi. 
nigdy nie zdecydowały się na przedstawienie żołnierzy walczących. $\mathrm{Na}$ większości plakatów pokazywano młodych, silnych chłopców, którzy $\mathrm{w}$ kolumnie energicznie ruszali przed siebie. Starano się maksymalnie wyciszyć bardzo niewygodny fakt, że wrogiem w rzeczywistości był rodak, często brat lub przyjaciel, dlatego nadużywano pojęć takich, jak wróg, nieprzyjaciel, obcy, faszysta lub komunista. Żadna ze stron nie uczestniczyła także w wojnie domowej. Frankiści prowadzili krucjatę przeciwko niewiernym, mając $w$ tym względzie pełną aprobatę Kościoła katolickiego i Watykanu. Natomiast republikanie brali udział w rewolucji społecznej, w której klasa pracująca walczyła o lepsze jutro z burżuazją i kapitalizmem.

\section{Bibliografia}

Carteles de la Guerra Civil Española, (1981). Madryt: Ediciones Urbión, SA.

Carulla, J., Carulla, A., (2000), El color de la guerra - The color of war. Spanish civil war. 19361939. Barcelona: Postermil, S.L.

Fontseré, C., (1978), El Sindicato de Dibujantes Profesionales, [w:] Carteles de la República y de la Guerra Civil. Barcelona: Editorial La Gaya Ciencia.

Grimau, C., (1979), El cartel republicano en la guerra civil. Madryt: Cuadernos Arte Cátedra.

Grimau, C., (1998), Cartel político y publicidad comercial, [w:] Arte del Franquismo. Madryt: Cuadernos Arte Cátedra.

García, M., (2008), Carteles para una guerra, carteles para una paz, [w:] Carteles de la Guerra Civil. Madryt: Fundación Pablo Iglesias.

Gubern, R., (2008), Retórica y estética del cartel bélico, [w:] Carteles de la Guerra Civil. Madryt: Fundación Pablo Iglesias.

Guerra, A., (2008), Arte e Historia, [w:] Carteles de la Guerra Civil. Madryt: Fundación Pablo Iglesias.

Jakson, G., (2008), La visión internacional de la guerra civil española, [w:] Carteles de la Guerra Civil. Madryt: Fundación Pablo Iglesias.

Julián González, I., (1993), El cartel republicano en la guerra civil española. Madryt: Ministerio de Cultura.

Julián González, I., (2008), Las paredes hablan, [w:] Carteles de la Guerra Civil. Madryt: Fundación Pablo Iglesias.

Miravitlles, J., Termes, J., (1978), Carteles de Guerra en España, [w:] Carteles de la República y de la Guerra Civil. Barcelona: Editorial La Gaya Ciencia.

Ramírez, J. A., (1998), Imágenes para un pueblo, [w:] Arte del Franquismo. Madryt: Cuadernos Arte Cátedra.

Renau, J., (1937), Función social del cartel publicitario. Valencia: Nueva Cultura. 


\section{Informacje na temat wykorzystanych w pracy plakatów:}

\section{Plakat 1}

Autor: Lorenzo Goñi, 1936

Tytuł: I tú? Que has fet per la victòria?

Wydawca: SDP-UGT, Barcelona 1936. Wymiary: 100x70 cm

\section{Plakat 2}

Autor: Josep Huertas, 1937

Tytuł: ¡Alerta está!

Wydawca: Graficás Reunidas, Madryt 1937. Wymiary: 90x63,2 cm

\section{Plakat 3}

Autor: Josep Huertas, 1937

Tytuł: PSOE. Agrupación Socialista Madrileña. Victoria: el Partido Socialista lanzará el caño-nazo final.

Wydawca: Graficás Reunidas, Madryt 1937. Wymiary: 100,3x70 cm

\section{Plakat 4}

Autor: José Bartasano, 1937

Tytuł: PCE. Madrid. Secretaría del Agit-Prop.

Wydawca: Unión Poligráfica, Madryt 1937. Wymiary: 94,5x66 cm

\section{Plakat 5}

\section{Autor: Ysacar, 1937}

Tytuł: UGT. Unión de Empleados de Oficinas. Nuestro "haber", copioso en partidas del heroísmo. ¡Superémoslo aún!

Wydawca: Graficás Reunidas, Madryt 1937. Wymiary: 98x70,2 cm

\section{Plakat 6}

Autor: Josep Renau, 1938

Tytuł: PCE. Madrid. $1^{\circ}$ de Mayo. Pasaremos. ;Ofensiva en todos los frentes!

Wydawca: Gráficas Valencia, Walencja 1938. Wymiary: 99,5x70 cm

\section{Plakat 7}

Autor: Cañavate, 1937

Tytuł: S.E el generalísimo.

Wydawca: Rivadeneyra, Madryt 1937. Wymiary: 110,7x79,4 cm

\section{Plakat 8}

Autor: Pedrero

Tytuł: El Generalísimo

Wydawca: Rivadeneyra, Madryt 1937. Wymiary: 100,3x70 cm

\section{Plakat 9}

Autor: Arteche, 1936

Tytuł: Les milicies, us necessiten!

Wydawca: Atlántida, A.G. Barcelona 1936. Wymiary: 140x100 cm 


\section{Plakat 10}

Autor: Pérez Contel

Tytuł: !Asesinos; ¿Quien al ver esto, no empuña un fusil para aplastar al fascismo destructor?

Wydawca: Gráficas Valencia, Walencja 1937. Wymiary: 99,6x67,5 cm

\section{Plakat 11}

Autor: Rivero Gil

Tytuł: !Atencion; Las enfermedades venéreas amenazan tu salud iPrevente contra ellas!

Wydawca: J. Aviño, Walencja 1937. Wymiary. 69,3x47,6 cm

\section{Plakat 12}

Autor: Melendreras, 1937

Tytut: Junta Delegada de Defensa de Madrid. Delegación de Propaganda y Prensa. Todas las milicias fundidas en el Ejército Popular.

Wydawca: Rivadeneyra, Madryt 1937. Wymiary: 111,5x80 cm

\section{Plakat 13}

Autor: Flos, 1939

Tytul: Yo cumplí!

Wydawnictwo: Subsidio al Combatiente, Comisión provinicial de Barcelona, Seix y Barral Hnos., Barcelona 1939. Wymiary: 100x70 cm

\section{Plakat 14}

Autor: Carlos Sáenz de Tejada

Tytuł: En nuestra justicia está nuestra fuerza.

Wydawnictwo: Auxilio Social, Imp.-Lit. Afrodisio Aguado, Valladolid-Palencia.

Wymiary: $100 \times 70 \mathrm{~cm}$

\section{Plakat 15}

Autor: nieznany

Tytuł: Pelayos.

Wydawnictwo: Artes Gráficas de la Comunión Tradicionalista, Malaga.

Wymiary: $100 \times 60 \mathrm{~cm}$

\section{Plakat 16}

Autor: nieznany

Tytuł: Arriba España.

Wydawnictwo: D.E.P.P.. Wymiary: $117 \times 83 \mathrm{~cm}$

\section{Plakat 17}

Autor: J. Cabanas

Tytuł: Por las armas. La Patria, el pan y la justicia.

Wydawnictwo: Servicio Nacional de Propaganda, Departamento de Plástica.

Wymiary: $100 \times 70 \mathrm{~cm}$

\section{Plakat 18}

Autor: Servicio Nacional de Propaganda (współpraca Carlos Sáenz de Tejada), 1939

Tytuł: $1^{\circ} \mathrm{Cruzada}$. España orientadora espiritual del mundo.

Wydawnictwo: Juan Barguño y Cía, Barcelona 1939. Wymiary: 100x70cm 
Plakat 19

Autor: Servicio Nacional de Propaganda, Departamento de Plástica, 1939

Tytuł: Ha llegado España!

Wydawca: Seix y Barral, Hnos., Barcelona 1939. Wymiary: 124x89 cm

Plakat 20

Autor: nieznany, 1939

Tytuł: España resucita!

Wydawca: Graf. Ultra, Barcelona 1939. Wymiary: 125x90 cm

\section{Plakat 21}

Autor: Paco Ribera

Tytuł: brak

Wydawca: Grafos, S.A. Barcelona. Wymiary: 100x70 cm 